\title{
Implementation of Unschooling Education Model as an Effort to Develop Tolerance Values
}

\author{
Sisilia Ayu Sulistyani \\ Universitas Pendidikan Indonesia. Jalan Dr. Setiabudhi No. 229, Bandung, Jawa Barat 40154. \\ sisiliaayusulistyani@upi.edu
}

\begin{abstract}
Humans have the ability to immerse into different levels of society. Due to the importance of tolerance values in this life, character education embodying tolerance values should be taught as early as possible. Home is the first school for children to understand tolerance values. However, how to teach the values of tolerance certainly requires an indepth study. Related to this, there is an educational model that develops tolerance values, namely the unschooling education model. This is a type of the homeschooling education where children are facilitated according to their learning needs at home. Parents and adults who live with the children play as facilitators of learning, for the children do not receive education like that of formal schools. Triangulation methods are used, namely comparing sources and theories, checking the data obtained from the fieldwork, namely secondary data collection and interviews. The results of the study show that children start to learn since they were born. The adults around the children need to continue learning because children are not only the recipients of knowledge. Therefore, unschooling education model is perceived of instrumental in the internalization of tolerance values in children from the early age.
\end{abstract}

Keywords: character education, tolerance values, unschooling education model

\section{Implementasi Model Pendidikan Unschooling sebagai Upaya dalam Mengembangkan Nilai-Nilai Toleransi}

\begin{abstract}
Abstrak
Manusia sebagai makhluk sosial tentunya harus memiliki kemampuan untuk beradaptasi dengan kondisi di berbagai lapisan masyarakat. Berbekal internalisasi nilai-nilai toleransi dalam diri setiap insan, pendidikan karakter terkait dengan nilai-nilai toleransi sebaiknya diajarkan sedini mungkin. Rumah sebagai sekolah dan madrasah pertama bagi anak merupakan sarana dan katalisator pengembangan nilai-nilai toleransi. Akan tetapi, bagaimana cara untuk mengajarkan nilai-nilai toleransi tersebut tentunya memerlukan sebuah kajian mendalam. Terkait dengan hal tersebut terdapat sebuah model pendidikan yang dapat diterapkan sebagai upaya pengembangan nilai-nilai toleransi yaitu model pendidikan unschooling. Model pendidikan unschooling sebagai variasi dari model pendidikan homeschooling, dimana anak difasilitasi sesuai dengan kebutuhan belajarnya di rumah dan orang tua atau orang dewasa yang tinggal bersama anak, merekalah fasilitator anak dalam belajar serta anak tidak mengenyam pendidikan seperti sistem pembelajaran di sekolah formal. Kajian dalam penelitian ini dianalisis secara kualitatif melalui penggunaan metode triangulasi, yaitu membandingkan sumber dan teori, melakukan pengecekan data-data yang diperoleh dari dua teknik pengumpulan data yaitu pengumpulan data sekunder dan wawancara. Hasil penelitian menunjukkan bahwa sejak dini di lingkungan pertama anak terlahir adalah garis awal kita sebagai fitrah dari Allah Swt untuk belajar. Orang dewasa di sekitar anak sebagai pembimbing pertama bagi anak perlu untuk terus belajar, karena tidak hanya anak sebagai penerima ilmu. Oleh sebab itu, implementasi model pendidikan unschooling efektif dan efisien dalam menjembatani internalisasi nilai-nilai toleransi pada anak sejak dini.
\end{abstract}

Kata Kunci: pendidikan karakter, nilai-nilai toleransi, model pendidikan unschooling

* Naskah diterima Agustus 2021, direvisi Oktober 2021, dan disetujui untuk diterbitkan November 2021

Dialog, 44(2), 2021, 152-165

https://jurnaldialog.kemenag.go.id, p-ISSN:0126-396X, e-ISSN:2715-6230

This is open access article under CC BY-NC-SA-License

(https://creativecommons.org/license/by-nc-sa/4.0/)

Dialog Vol. 44, No.2, Desember 2021

152 


\section{A. Pendahuluan}

Pendidikan merupakan sebuah usaha yang menjadi pondasi dalam pembentukan karakter anak di masa depan. Alquran sebagai panduan umat beragama Islam tentunya berperan penting dalam memperkuat pondasi pada pendidikan anak usia dini. Sebagaimana firman Allah yang dijelaskan dalam Q.S At-Tahrim:6 yang mengandung arti "Hai orang-orang yang beriman, peliharalah dirimu dan keluargamu dari api neraka yang bahan bakarnya adalah manusia dan batu; penjaganya malaikat-malaikat yang kasar, keras, dan tidak mendurhakai Allah terhadap apa yang diperintahkan-Nya kepada mereka dan selalu mengerjakan apa yang diperintahkan". Dengan demikian, dapat ditarik benang merah bahwa dalam menerapkan sebuah model pendidikan membutuhkan peran setiap insan terutama orang tua sebagai madrasatul 'ula yang memegang peran kunci untuk memfasilitasi tumbuh kembang sang anak. Sebagaimana yang dikatakan oleh Ki Hajar Dewantoro "Jadikanlah setiap orang sebagai guru. Setiap rumah sebagai sekolah. Pendidikan tak berhenti di bangunan sekolah, tapi juga di rumah dan dimana saja".

Berbagai jenis model pendidikan yang dapat diterapkan dalam proses pendampingan tumbuh kembang anak yang juga mempertimbangkan tahapan psikologi belajar dan psikologi perkembangan dapat diterapkan oleh orangtua. Salah satunya yakni model pendidikan unschooling. Beberapa praktisi pendidikan juga menjelaskan terkait dengan model pendidikan unschooling di antaranya Wheatley (2009) yang menyatakan bahwa homeschoolers may do "school at home" and follow a set curriculum, unschoolers learn primarily through everyday life experiencesexperiences that they choose and that therefore automatically match their abilities, interests, and learning styles (Gray, 2013). Bahkan sebagian besar orang yang mengimplementasikan model pendidikan ini memiliki pendapat senada bahwa setiap anak berhak mendapatkan pembelajaran dari apa yang mereka butuhkan, tanpa interferensi atau paksaan dari orang dewasa di sekeliling mereka. Argumen tersebut beriringan dengan pernyataan yang diungkapkan oleh John Holt (1977); "Children want to learn about the world, are good at it, and can be trusted to do it without much adult coercion or interference"(Gray, 2013).

Dengan demikian, dapat ditarik kesimpulan bahwa model pendidikan memfokuskan orang tua untuk mendampingi anak sesuai dengan minat dan bakat dengan menggunakan metode pembelajaran yang disesuaikan dengan kebutuhan anak dan menjadikan rumah sebagai tempat belajar.

Bersesuaian dengan pemaparan sebelumnya, rumah sebagai tempat pendidikan pertama dan utama bagi anak sebenarnya telah menerapkan metode pembelajaran unschooling bagi anak, dimulai dari membelajarkan anak berbicara, berjalan, makan, dan sebagainya. Hal-hal tersebut tentunya tidaklah terstruktur dan tidak ada dokumen kurikulum khusus secara tertulis sebagai perencanaan dan pedoman pelaksanaannya. Tentunya, hal ini membutuhan sebuah ruang lingkup pendukung yang baik dimulai dari perencanaan yang matang, metode pembelajaran, dan tolok ukur yang tepat dalam mewakili pencapaian belajar anak. Adapun beberapa metode yang dapat diimplementasikan pada pendidikan unschooling, yakni (a) pembiasaan; (b) keteladanan; (c) pembinaan; dan (d) nasihat (Hadisaputra, 2020).

Dengan demikian, tujuan dari penulisan artikel ini adalah untuk memberikan data faktual yang komprehensif dalam pemaparan terkait empat aspek utama yang anak pelajari dalam keluarga sebagai upaya mengembangkan nilai-nilai toleransi, dengan mengimplementasikan pendidikan unschooling yaitu (a) aspek pengetahuan dalam internalisasi nilai-nilai toleransi; (b) aspek sikap dalam arti sebagai pengenalan pada nilai-nilai toleransi; (c) aspek keterampilan dalam arti yang dilakukan melalui pengadaan pelatihan-pelatihan tentang toleransi; dan (d) aspek lingkungan dalam arti menciptakan lingkungan yang 
kondusif sebagai sarana internalisasi nilainilai toleransi.

\section{B. Metode Penelitian}

Penelitian ini merupakan penelitian kualitatif dengan menggunakan metode triangulasi, yaitu membandingkan sumber dan teori, melakukan pengecekan data-data yang diperoleh dari dua teknik pengumpulan data yaitu pengumpulan data sekunder dan wawancara.

Penyajian data sekunder berupa beberapa referensi terkait fokus penelitian yang sesuai dengan tema atau topik. Kemudian membaca, mencatat, menganalisis dan atau menyimpulkan isi tulisan pada jurnal ilmiah, buku atau hasil penelitian lainnya yang bertujuan untuk mendeskripsikan, menjelaskan dan atau merekontruksi suatu fenomena atau permasalahan. Disamping itu, untuk menunjang hasil penelitian, peneliti juga melakukan wawancara kepada seorang narasumber yang telah mengimplementasikan model pendidikan unschooling kepada para anaknya di rumah. Penulis memilih narasumber tersebut dikarenakan data faktual yang dapat diperoleh dari narasumber, sehingga tidak mengurangi derajat keyakinan hasil penelitian yang diharapkan. Narasumber juga telah mengimplementasikan model pendidikan unschooling ini selama 7 tahun dan berkelanjutan pada anak berikutnya hingga saat ini. Metode wawancara ini dilakukan secara daring dengan pertimbangan guna meminimalisir resiko maupun kendala di masa pandemi covid 19.

\section{Hasil dan Pembahasan}

Merujuk pada rumusan masalah yang telah dijabarkan oleh penulis pada bagian pendahuluan, maka beberapa komponen yang akan dibahas pada bagian ini adalah sebagai berikut:

\section{Model Pendidikan Unschooling}

Mendengar istilah unschooling, hal pertama yang terlintas di pikiran kita adalah tidak mengenyam pendidikan atau mengenyam pendidikan tapi tidak di sekolah formal. Istilah ini sering dikaitkan dengan homeschooling yang notabene sudah tidak asing lagi kita mendengarnya. Sebagian besar masyarakat menganggap bilamana mengenyam pendidikan, maka haruslah bersekolah, entah itu di Sekolah atau di rumah. Namun yang jelas harus mengikuti peraturan pendidikan umumnya terkait dengan standar capaian pembelajaran yang telah ditetapkan oleh pemerintah. Sebuah penelitian bahkan mencatat pada tahun 2017, The National Center for Education Statistics mencatat hampir 1,8 juta anak di Amerika merupakan anak homeschooling. Tentunya jumlah ini lebih sedikit bilamana dibandingkan dengan anak yang mengenyam pendidikan di sekolah formal.

Istilah unschooling memang masih jarang didengar oleh kita, bahkan ada yang beranggapan bahwa istilah ini memiliki makna yang sama dengan homeschooling. Akan tetapi, sebenarnya istilah unschooling itu berbeda dengan homeschooling.

Istilah unschooling pertama kali digunakan di Amerika dipelopori oleh seorang akademisi bernama John Holt pada tahun 1977, bersama dengan terbitnya karya beliau yang berjudul Growing without Schooling (GWS). Unschooling merupakan sebuah model pendidikan tanpa melibatkan sistem persekolah yang diaplikasikan pada anak-anak, dimana orangtua dan/ atau orang dewasa di sekitar anak tersebutlah yang menjadi sekolah atau madrasah bagi anak. Sebagaimana yang dipaparkan oleh Gina Riley dalam artikelnya bahwa "Unschooling is a variation of homeschooling where, instead of following a set curriculum, children learn through everyday life experiences" (Riley, 2018: 2). Wheatley mendukung pemaparan Riley yang mana unschooling dianggap memberikan keuntungan jika diterapkan yakni "These experiences are generally, of their choosing, and tend to match their strengths, interests, and personal learning styles"(Wheatley, 2009 dalam Riley, 2018).

Merujuk pada kedua teori tersebut dapat disimpulkan bahwa model pendidikan unschooling ini memberikan ruang bagi anak untuk mengeksplor dirinya, 
memilih dan mengaitkan kelebihan, ketertarikan, dan gaya belajar yang mereka miliki. Tidak seperti di sekolah yang belajar bersama guru, dengan kurikulum dan berstandarkan capaian pembelajaran, pendidikan unschooling membelajarkan anak kapanpun dan dimanapun.

Adapun beberapa pertimbangan dalam menerapkan model pendidikan unschooling ini di antaranya perlunya kolaborasi antar orangtua/ orang dewasa sebagai fasilitator belajar anak, kreatifitas dalam menyediakan sarana pembelajaran, kemampuan bernegosiasi dengan anak, kematangan diri orang dewasa sebagai orang terdekat bagi anak, dan unschooling tidak memiliki kurikulum formal, materi pembelajaran, jenjang pendidikan, dan tes/ujian. Hal tersebut perlu dikemas berlandaskan motivasi dalam diri untuk menjadikan lingkungan dan individu di sekitar anak sebagai media belajar yang baik dan menunjang akulturasi pendidikan. Sebagaimana yang diungkap oleh John Holt, seorang praktisi pendidikan dari Amerika, ia menyebutkan bahwa "Learning is a natural breathing" (Holt, 1967). Pernyataan tersebut senada dengan pernyataan Deci dan Richard Ryan yakni;

"Intrinsic motivation is clearly a manifestation of our natural human propensity to assimilate and integrate knowledge. Characterized by curiosity and interest, intrinsic motivation represents the prototype of an active and willing acquisition and integration of knowledge" (Deci \& Ryan, 2008).

Dengan demikian, kelebihan unschooling dalam mendukung tumbuh kembang, yaitu;

"There are many reasons why you might choose to unschool your child. The benefits of unschooling include: (a) providing a safer learning environment, (b) improving learning outcomes with more effective teaching methods, teaching your child in a manner that s more inline with your family's values, and (d) providing a customized, tailored approach to your child" (Eleesha Lockett, 2019).

Merujuk kembali pada Deci dan Ryan yang menyatakan bahwa "A sense of competence comes from success experiences and overall positive feelings about activities, and fosters feelings of intrinsic motivation. Children, by nature, are driven by a need for competence" (Deci \& Ryan, 2008). Pernyataan tersebut dapat dimaknai kemauan untuk memiliki kompetensi berasal dari pengalaman belajar yang sukses dan perasaan positif yang berkolaborasi dalam aktifitas belajar, hingga akhirnya menumbuhkan motivasi dalam diri anak secara alami. Hal tersebut merupakan pondasi yang penting dan perlu dibangun dalam diri anak sedini mungkin. Sebagai orang tua atau orang dewasa di sekitar anak, tentunya kita tidak akan dapat menemani anak sepanjang waktu, mereka kelak harus berdiri sendiri di atas kedua kakinya, sehingga motivasi intrinsik ini diharapkan dapat mendorong kebutuhan anak dalam berbagai kondisi.

Sebuah data mencatat pada tahun 2006 di Amerika jumlah anak unschooling mencapai 150.000 anak. Data terbarukan mencatat sekitar 13\% anak di Amerika belajar dengan model pendidikan unschooling (Eleesha Lockett, 2019).Data tersebut tentunya bersifat fluktuatif, namun akan sulit untuk menemukan persentasenya di tahun-tahun terakhir ini (Keifer \& Effenberger, 1967).

2. Pendidikan Karakter di Indonesia

Secara etimologi karakter berasal dari bahasa Latin yaitu "character" yang mengandung arti watak, tabiat, sifat-sifat kejiwaan, budi pekerti, kepribadian, atau akhlak. Sedangkan secara harfiah, karakter berarti sifat manusia pada umumnya dimana manusia mempunyai banyak sifat yang tergantung dari faktor kehidupannya sendiri. Pada konteks ini, dapat ditelisik bahwa proses pembentukan karakter pada anak mencakup nilai baik dan nilai buruk.

Berkaitan dengan pernyataan penulis di atas erat kaitanya dengan tujuan sistem pendidikan nasional Indonesia yang terdapat dalam UU RI No. 20 Tahun. 2003 tentang Sistem Pendidikan Nasional Pasal 1 Ayat (3) yang berbunyi, "Sistem pendidikan nasional adalah keseluruhan 
komponen pendidikan yang saling terkait secara terpadu untuk mencapai tujuan pendidikan nasional". Adapun terminologi pendidikan karakter pada anak yang juga termaktub dalam Undang-Undang No. 20 Tahun 2003 Bab II tentang Dasar, Fungsi, dan Tujuan Pasal 3 yang berbunyi;

"Pendidikan nasional berfungsi mengembangkan kemampuan dan membentuk watak serta peradaban bangsa yang bermartabat dalam rangka mencerdaskan kehidupan bangsa, bertujuan untuk berkembangnya potensi peserta didik agar menjadi manusia yang beriman dan bertakwa kepada Tuhan Yang Maha Esa, berakhlak mulia, sehat, berilmu, cakap, kreatif, mandiri, dan menjadi warga negara yang demokratis serta bertanggung jawab" (Indonesia, 2003).

Dengan demikian, amanah ketetapan di atas yakni internalisasi nilai-nilai kebaikan dalam aktualisasi pendidikan karakter pada anak dan salah satunya adalah nilai-nilai toleransi sebagai harapan untuk menjadi manusia yang beriman dan bertakwa kepada Tuhan Yang Maha Esa, berakhlak mulia, sehat, berilmu, cakap, kreatif, mandiri, dan menjadi warga negara yang demokratis serta bertanggung jawab. Dilansir dalam laman Kementerian Pendidikan Nasional, Suyanto (2010) memaparkan bahwa terdapat sembilan pilar pendidikan karakter, yaitu (a) cinta Tuhan dan segenap ciptaany-Nya, (b) kemandirian dan tanggung jawab, (c) kejujuran atau amanah dan diplomatis, (d) hormat dan santun, (e) dermawan, suka tolong menolong dan gotong-royong atau kerja sama, (f) percaya diri dan kerja keras, (g) kepemimpinan dan keadilan, (h) baik dan rendah hati, dan (i) toleransi, kedamaian dan kesatuan, disamping juga memperhatikan K4 (Kesehatan, Kebersihan, Kerapihan, dan Keamanan) (Suyanto dalam Yuslaini, 2018).

Resapan nilai-nilai toleransi dalam pendidikan karakter anak menjadi sebuah urgensi mengingat demoralisasi dan degradasi pengetahuan maupun keberagaman sudah sedemikian menyatu pada berbagai lapisan masyarakat.

3. Konsep dan Cakupan Nilai-Nilai Toleransi

Kata toleransi secara etimologis berasal dari bahasa Latin yaitu tolere yang berarti mengangkat (to lift up). Istilah ini dikenal sangat baik di daerah dataran Eropa, terutama saat revolusi Perancis. Hal tersebut berkaitan dengan slogan kebebasan, persamaan, dan persaudaraan (Ceadel, 1983). Sedangkan, dalam kamus Latin makna toleransi berasal dari kata tolere yang berarti menanggung (to bear), memikul (endure), menopang (sustain) dan bersabar (patient) (Beard, J. R., \& Beard, 1968). Adapun makna toleransi menurut UNESCO yakni "Tolerance is respect, acceptance and appreciation of the rich diversity of our world's cultures, our forms of expression and ways of being human" (Azoulay, 2017). Di sisi lain, Vogt (1977) menjelaskan bahwa toleransi merupakan keterampilan dan pemahaman yang diperlukan oleh setiap individu untuk dapat bertahan dalam dunia yang penuh dengan keragaman (Nuswantari, 2018).

Dengan demikian, makna toleransi dapat diindikasikan sebagai sikap atau tingkah laku seorang individu untuk sabar dalam memikul dan menopang beban terhadap sesuatu yang berbeda demi menjunjung persaudaraan, baik dalam cakupan perbedaan pendapat, budaya, keyakinan, maupun praktik peribadatan.

Butir-butir toleransi telah dijabarkan dalam buku Living Values Activities for Children (Tillman, 2001) yaitu sebagai berikut:

a. Tujuannya adalah kedamaian, metodenya adalah toleransi;

b. Toleransi berarti menjadi terbuka dan menerima keindahan perbedaan;

c. Toleransi adalah penghargaan timbal balik lewat pemahaman yang juga timbal balik;

d. Benih-benih intoleransi adalah ketakutan dan keacuhan;

e. Benih-benih toleransi adalah cinta dialiri oleh kasih sayang dan perhatian;

Dialog Vol. 44, No.2, Desember 2021 
f. Mereka yang mengetahui bagaimana cara menghargai kebaikan orang lain dan situasi-situasi adalah orang yang toleransi;

g. Toleransi menghargai individualitas dan perbedaan sambil menghilangkan topeng-topeng pemecah belah dan mengatasi ketegangan akibat keacuhan;

h. Toleransi adalah kemampuan untuk menghadapi situasi-situasi sulit;

i. Untuk mentolerir ketidaknyamanan hidup adalah dengan melepaskan, santai, membuat orang lain merasa santai dan terus melangkah maju.

Adapun bilamana nilai-nilai toleransi tersebut dikaitkan dengan pendidikan bagi anak, nilai-nilai tersebut dapat diukur dengan kulminasi indikator sebagaimana dijabarkan pada tabel dibawah ini;

Tabel 1. Indikator Nilai-Nilai Toleransi pada Pendidikan Anak

\begin{tabular}{|c|c|c|}
\hline No. & Sub Variabel & Indikator \\
\hline 1. & Kedamaian & $\begin{array}{l}\text { a. Bermusyawarah } \\
\text { untuk } \\
\text { memecahkan } \\
\text { masalah } \\
\text { b. Berbicara dengan } \\
\text { nada yang baik }\end{array}$ \\
\hline 2. & Terbuka & $\begin{array}{l}\text { a. Menerima saran } \\
\text { dari orang lain } \\
\text { b. Berani } \\
\text { mengungkapkan/ } \\
\text { tidak malu } \\
\text { bertanya bila } \\
\text { menghadapi } \\
\text { kesulitan belajar }\end{array}$ \\
\hline 3. & $\begin{array}{l}\text { Menerima } \\
\text { Keindahan } \\
\text { Perbedaan }\end{array}$ & $\begin{array}{l}\text { a. Mau berteman } \\
\text { dengan siapa saja } \\
\text { b. Tidak marah/ } \\
\text { kesal apabila } \\
\text { pendapat tidak } \\
\text { disetujui } \\
\text { c. Menghargai hak } \\
\text { asasi setiap orang }\end{array}$ \\
\hline 4. & $\begin{array}{c}\text { Penghargaan Timbal } \\
\text { Balik }\end{array}$ & $\begin{array}{l}\text { a. Memberikan } \\
\text { apresiasi bagi } \\
\text { kesuksesan } \\
\text { teman } \\
\text { b. Membalas } \\
\text { ucapan salam } \\
\text { dari teman/ guru }\end{array}$ \\
\hline
\end{tabular}

\begin{tabular}{|c|c|c|}
\hline 5. & $\begin{array}{c}\text { Pemahaman Timbal } \\
\text { Balik }\end{array}$ & $\begin{array}{l}\text { a. Membantu } \\
\text { teman } \\
\text { memahami } \\
\text { materi } \\
\text { pembelajaran } \\
\text { b. Berbagi pada } \\
\text { teman yang } \\
\text { membutuhkan }\end{array}$ \\
\hline 6. & $\begin{array}{c}\text { Cinta dan Kasih } \\
\text { Sayang }\end{array}$ & $\begin{array}{l}\text { Merasa senang } \\
\text { atas pertemanan } \\
\text { yang dijalin dan } \\
\text { kehilangan bila } \\
\text { ada teman yang } \\
\text { tidak hadir }\end{array}$ \\
\hline 7. & Perhatian & $\begin{array}{l}\text { Memberikan } \\
\text { nasehat untuk } \\
\text { kesuksesan } \\
\text { teman }\end{array}$ \\
\hline 8. & $\begin{array}{c}\text { Menghargai Kebaikan } \\
\text { Orang Lain }\end{array}$ & $\begin{array}{l}\text { Mengucapkan } \\
\text { rasa terima kasih } \\
\text { atas segala } \\
\text { bantuan yang } \\
\text { diterima }\end{array}$ \\
\hline 9. & $\begin{array}{l}\text { Menghargai Situasi- } \\
\text { Situasi Orang Lain }\end{array}$ & $\begin{array}{l}\text { Mampu } \\
\text { memposisikan } \\
\text { diri dalam situasi } \\
\text { orang lain }\end{array}$ \\
\hline
\end{tabular}

Sumber: (Tillman, 2004)

Berdasarkan pada indikator di atas, tolok ukur nilai-nilai toleransi yang diajarkan pada anak perlu mencapai dan memperhatikan hal-hal tersebut. Adapun indikator tersebut tercakup dalam empat kemampuan belajar anak, yaitu pengetahuan (kognitif), sikap (psikomotor), keterampilan (afektif), dan lingkungan yang akan penulis jabarkan pada bagian selanjutnya.

4. Aspek Pengetahuan (Kognitif) dalam Implementasi Model Pendidikan Unschooling sebagai Upaya dalam Mengembangkan Nilai-Nilai Toleransi

Pengembangan nilai-nilai toleransi yang erat kaitannya dengan aspek sosial menganalogikan sebuah implementasi pendukung kemampuan kognitif sosial 
pada anak. Teori kognitif sosial dikembangkan oleh Albert Bandura yang menyatakan bahwa faktor sosial, kognitif, dan juga perilaku, memainkan peran penting dalam pembelajaran. Bandura menggambarkan ketiga faktor tersebut dalam sebuah model determinasi reciprocal dibawah ini;

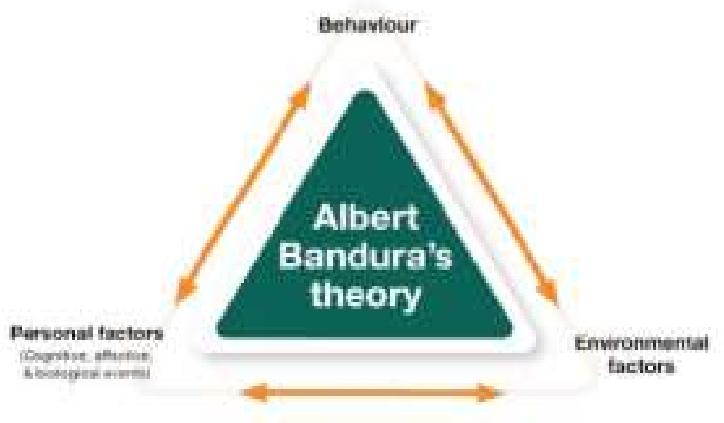

Gambar 1. Model Determinasi Reciprocal (Marhayati et al., 2020)

Adapun faktor kognitif yang dimaksud yakni berupa ekspektasi siswa untuk meraih keberhasilan, faktor sosial mencakup pengamatan siswa terhadap perilaku orang tua dan lingkungannya. Dengan demikian, teori ini mengakui adanya kontribusi sosial terhadap cara manusia berpikir dan bertindak, maupun pentingnya proses kognitif terhadap motivasi, emosi, dan tindakan.

Dalam pendekatan pentahapan yang bersifat khusus, kita mengenal pentahapanpentahapan dari Piaget, Kohlbeig, Erikson, dan sebagainya. Jean Piaget mengemukakan tahap-tahap perkembangan dari kemampuan kognitif anak. Dalam perkembangan kognitif menurut Piaget yang terpenting adalah penguasaan dan kategori konsep-konsep. Melalui penguasaan konsep-konsep itu, anak diharapkan dapat memecahkan berbagai problema yang dihadapi dalam kehidupannya.

Ada empat tahap perkembangan kognitif anak menurut konsep Piaget digambarkan pada tabel di bawah ini (Syah, 2012):
Tabel 2 Tahap Perkembangan Kognitif Anak Menurut Piaget

\begin{tabular}{|c|c|c|}
\hline Tahap & $\begin{array}{c}\text { Perkiraan } \\
\text { Usia }\end{array}$ & Pencapaian Utama \\
\hline Sensorimotor & $\begin{array}{c}\text { Lahir } \\
\text { hingga 2 } \\
\text { tahun }\end{array}$ & $\begin{array}{c}\text { Pembentukan konsep "keajekan objek dan kemajuan } \\
\text { bertahap pada perilaku refleks ke perilaku yang } \\
\text { diarahkan oleh tujuan. }\end{array}$ \\
\hline Praoperasi & $\begin{array}{c}2 \text { sampai 7 } \\
\text { tahun }\end{array}$ & $\begin{array}{c}\text { Perkembangan kemampuan menggunakan simbol untuk } \\
\text { melambangkan objek di dunia ini. Pemikiran masih terus } \\
\text { bersifat egosentris dan terpusat. }\end{array}$ \\
\hline Operasi & $\begin{array}{c}7 \text { sampai } \\
\text { Konkret }\end{array}$ & $\begin{array}{c}\text { Perbaikan kemampuan berpikir logis. Kemampuan baru } \\
\text { meliputi penggunaan pengoperasian yang dapat dibalik. } \\
\text { Pemikiran tidak terpusat dan pemecahan masalah } \\
\text { kurang dibatas oleh egosentrisme. Pemikiran abstrak } \\
\text { tidak memungkinkan }\end{array}$ \\
\hline $\begin{array}{c}\text { Operasi } \\
\text { Formal }\end{array}$ & $\begin{array}{c}11 \text { tahun } \\
\text { hingga } \\
\text { dewasa }\end{array}$ & $\begin{array}{r}\text { Pemikiran abstrak dan semata-mata simbolik } \\
\text { dimungkinkan. Masalah dapat dipecahkan melalui } \\
\text { penggunaan eksperimentasi sistematik. }\end{array}$ \\
\hline
\end{tabular}

Sebelum membahas terkait dengan keterkaitan hasil penelitian dengan pembahasan yang dipaparkan oleh penulis sebelumnya, dalam penelitian ini penulis mewawancarai seorang implementor dan praktisi model pendidikan unschooling yang telah 7 tahun mengaplikasikan model pendidikan unschooling sebagai pendidikan utama dalam keluarganya. Narasumber tersebut bernama Brynna Rafferty-Brown. Dikarenakan pengalamannya dalam mengaplikasikan model pendidikan unschooling dalam kurun waktu yang cukup lama, maka penulis tertarik untuk menjadikannya sebagai narasumber yang dapat memberikan data faktual dan komprehensif sebagai pendukung hasil penelitian sesuai tujuan yang diharapkan.

Berdasarkan hasil wawancara yang dilakukan oleh penulis bersama narasumber, faktor kognitif sering dipahami sebagian besar orang erat kaitannya dengan lingkup pengetahuan anak terhadap keilmuan yang ia pelajari, sehingga pencapaian kogitif anak biasanya terukur dari pencapaian nilai pengetahuan anak di sekolah. Kelirunya, orang dewasa di sekitar anak tersebut, baik orang tua, guru, dan sebagainya kurang peka untuk mengaitkan 
alasan anak belajar sebuah ilmu baru dengan kenyataan yang akan ia alami kelak. Padahal anak akan lebih mudah memahami sesuatu, bilaman dikaitkan dengan dunia mereka. Narasumber juga menjelaskan bahwa ketika beliau menerapkan model pendidikan unschooling kepada ketiga anaknya, beliau tidak memaksa mereka untuk belajar mata pelajaran sesuai dengan anak sebaya lainnya yang mengenyam pendidikan di sekolah umum. Terlintas penulis menanyakan terkait "Apakah narasumber tidak merasa khawatir bilamana anaknya jauh tertinggal dari anak sebayanya?" Dan narasumber menjawab bahwa hal tersebut bukanlah sebuah kegundahan bagi dia dan suami, karena keluarga mereka bersepakat untuk membangun sebuah pondasi yang mengutamakan pembentukan karakter anak dan mereka tidak ingin memaksakan anak untuk mempelajari hal yang mereka tidak sukai. Mereka beranggapan bahwa kemampuan kognitif dalam lingkup pengetahuan, misalnya pembelajaran mengenai penjumlahan itu dapat diajarkan secara langsung kepada anak melalui kehidupan sehari-hari mereka. Sebagai contoh, ketika narasumber memiliki keperluan untuk berbelanja ke Supermarket, maka ia akan mengajak anak-anaknya untuk berbelanja dan membantu melihat harga barang, membantu mengecek harga barang pada mesin yang tersedia, dan lain sebagainya. Hal tersebut secara langsung tentunya membelajarkan anak terkait dengan penjumlahan, pengurangan, dan konsep matematika lainnya. Anak juga secara langsung belajar untuk beradaptasi dengan orang lain di lingkungan sekitarnya, seperti bagaimana mereka meningkatkan rasa toleransi untuk mengantri saat di kasir. Dengan demikian, pendidikan unschooling tidak membatasi kita untuk menunjang pencapaian aspek pengetahuan (kognitif). Orang tua sebagai orang dewasa yang terdekat dengan anak, perlu lebih kreatif dalam mengemas pembelajaran.

Disamping itu, narasumber juga menjelaskan jikalau tidak semua pemahaman yang anak-anaknya sukai, namun narasumber dan suami, maupun kerabat tidak ada yang memfasilitasi siswa, maka narasumber akan meminta bantuan pada tenaga ahli, seperti tutor. Implementasinya narasumber meminta bantuan pada tutor untuk mengajarkan Bahasa Indonesia yang baik kepada anakanak, karena Bahasa Indonesia merupakan Bahasa yang sangat dihargai di keluarga mereka. Selain, narasumber dan suami yang memang bekerja dan intensitas mereka untuk pergi ke Indonesia cukup banyak.

Anak tidak merasa terbebani dengan apa yang dia pelajari, tentunya hal tersebut akan lebih memacu perkembangan anak dari berbagai aspek. Tidak hanya kognitif intrinsik, melainkan juga kognitif ekstrinsik. Sebagaimana dikemukakan oleh Sweller bahwa beban kognitif dalam memori kerja dibagi menjadi tiga macam berdasarkan sumber penyebabnya yaitu beban kognitif intrinsik (intrinsic cognitive load), beban kognitif ekstrinsik (extraneous cognitive load), dan beban kognitif kontruktif (germane cognitive load) (Zulfi et al., 2018).

Dapat disimpulkan bahwa pengembangan aspek pengetahuan (kognitif) yang dilakukan narasumber melalui model pendidikan unschooling tetap dapat tercapai sesuai dengan kebutuhan anak, bahkan memberi ruang bagi anak untuk lebih banyak mengeksplor pengetahuan yang membuatnya tertarik, sehingga nilai-nilai toleransi dalam diri anak juga akan semakin terasah.

5. Aspek Sikap (Psikomotor) dalam Implementasi Model Pendidikan Unschooling sebagai Upaya dalam Mengembangkan Nilai-Nilai Toleransi

Aspek sikap (psikomotor) ini erat kaitannya dengan hasil belajar yang pencapaiannya dilakukan melalui keterampilan manipulasi yang melibatkan otot dan kekuatan fisik. Adapun menurut Mardapi (2003) terdapat enam tahap dalam keterampilan psikomotor, yaitu gerak refleks, gerakan dasar, kemampuan perseptual, gerakan fisik, gerakan terampil, dan komunikasi nondiskursif (Nurwati, 2014). Gerakan refleks adalah respons motorik atau gerak tanpa sadar yang 
muncul ketika bayi lahir. Gerakan dasar adalah gerakan yang mengarah pada keterampilan komplek yang khusus.

Sebagaimana pengalaman yang dibagi oleh narasumber, bahwa anak-anak beliau menjadi lebih eksploratif dan mawas diri diiringi tentunya dengan rasa toleransi, karena narasumber menyadari seorang anak tidak hanya butuh "tahu", melainkan yang lebih penting adalah "paham". Setelah mereka paham, maka nilai-nilai pembelajaran yang diharapkan akan terisolir membentuk akulturasi karakter yang menjadi indikator toleransi, seperti rasa terbuka untuk menerima saran dari orang lain dan berani mengungkapkan atau tidak malu untuk bertanya bila menghadapi kesulitan belajar.

Dengan demikian, kemampuan penunjang lainnya diharapkan dapat terangsang. Kemampuan tersebut termasuk dalam lingkup aspek psikomotor, yaitu (a) kemampuan perseptual merupakan kombinasi kemampuan kognitif dan motorik atau gerak; (b) kemampuan fisik adalah kemampuan untuk mengembangkan gerakan terampil; (c) gerakan terampil adalah gerakan yang memerlukan belajar, seperti keterampilan dalam olahraga; (d) komunikasi nondiskursif adalah kemampuan berkomunikasi dengan menggunakan gerakan. Teori lain yang bersesuaian juga dijelaskan oleh Butler (1972) yang membagi hasil psikomotor ke dalam tiga hal, yaitu specific responding, motor chaining, rule using (Nurwati, 2014). Pada tingkat specific responding anak mampu merespon hal-hal yang sifatnya fisik (yang dapat didengar, dilihat, atau diraba) atau melakukan keterampilan yang sifatnya tunggal, misalnya memegang raket untuk badminton. Lalu, pada tingkat motor chaining anak sudah mampu menggabungkan lebih dari dua keterampilan dasar menjadi satu keterampilan gabungan, misalnya memukul bola, menggunakan jangka sorong, dan sebagainya. Sedangkan pada tingkat rule using anak sudah dapat menggunakan pengalamannya untuk melakukan keterampilan yang kompleks, misalnya bagaimana secara tepat agar dengan tenaga yang sama hasilnya menjadi lebih baik dan tepat sasaran.

Adapun taksonomi Bloom dijelaskan bahwa aspek psikomotor terbagi menjadi beberapa kategori di antaranya sebagai berikut (Almutairi et al., 2020):

1) Meniru

Kategori meniru ini merupakan kemampuan untuk melakukan sesuatu dengan contoh yang diamatinya walaupun belum dimengerti makna ataupun hakikatnya dari keterampilan itu. Sebagaimana diungkap California Department of Education, hingga usia 18 bulan, anak biasanya meniru gerakan orangtua. Pada usia 3 tahun, anak mulai meniru perilaku, sopan-santun, dan bahasa orangtuanya (Si Kecil Peniru Alami, 2021)

2) Memanipulasi

Kategori ini merupakan kemampuan dalam melakukan suatu tindakan serta memilih apa yang diperlukan dari apa yang diajarkan. Seiring dengan hal tersebut Katrena,dkk menekankan bahwa perkembangan gerak manipulatif ditandai adanya keterampilan memanipulasi obyek sambil bergerak (Rahmah et al., 2019).

3) Pengalamiahan

Kategori ini merupakan suatu penampilan tindakan dimana hal yang diajarkan dan dijadikan sebagai contoh telah menjadi suatu kebiasaan dan gerakangerakan yang ditampilkan lebih meyakinkan.

\section{4) Artikulasi}

Kategori ini merupakan suatu tahap dimana seseorang dapat melakukan suatu keterampilan yang lebih kompleks terutama yang berhubungan dengan gerakan interpretatif.

Dapat disimpulkan bahwa aspek psikomotor ini berkaitan dengan segala sesuatu yang berhubungan dengan aktivitas otot, fisik, atau gerakan-gerakan anggota badan yang hasil keluarannya bersifat psikomotoris setelah mengalami peristiwa belajar.

Berkaitan dengan pembahasan sebelumnya terdapat sebuah pengalaman 
yang dibagikan oleh narasumber, dimana ia suka mengajak anak-anak ke sebuah taman dekat rumah. Anak-anak tidak hanya percaya diri untuk bermain dengan teman sebaya, namun merekapun berani untuk bermain bersama anak-anak lainnya yang di atas usianya. Tentunya ketika seorang anak bermain, selain mereka merasa senang, mereka akan mengalami sebuah pengalaman belajar yang mana tidak terbatasnya mereka untuk bermain dengan siapapun. Tak perlu dengan teman sebayanya. Pengalaman belajar tersebut tentunya menjadi katalisator bagi anak untuk mempelajari nilai-nilai toleransi, selain mereka menstimulus diri melalui aktivitas fisik/ otot/ gerakan anggota badan.

Disamping itu, narasumber juga berbagi cerita terkait seorang anak diseleksi yang memiliki orangtua hebat, dimana orangtua tersebut sangat mendukung tumbuh kembang anaknya, tanpa memberikan label yang menyudutkan bahwa anaknya berbeda dengan anak lainnya. Hingga suatu ketika, anak tersebut dengan bakatnya menggambar, ia ingin belajar menggambar dengan seorang ahli. Anak tersebut dapat mengasah keterampilan psikomotoriknya dengan meniru bahkan melakukan artikulasi yang lebih pesat disbanding anakanak pada umunya. Hal ini semakin meyakinkan bahwa peran orangtua sangatlah berpengaruh dalam meleburkan nilai-nilai karakter termasuk nilai toleransi terhadap diri anak itu sendiri.

6. Aspek Keterampilan (Afektif) dalam Implementasi Model Pendidikan Unschooling sebagai Upaya dalam Mengembangkan Nilai-Nilai Toleransi

Aspek keterampilan (afektif) memiliki hubungan yang erat dalam upaya pengembangan nilai-nilai toleransi. Hal ini disebabkan karena aspek ini berhubungan dengan sikap, nilai, perasaan, emosi, serta derajat penerimaan atau penolakan suatu objek dalam kegiatan belajar mengajar.

Adapun Karthwohl \& Bloom membagi aspek ini menjadi lima kategori yaitu sebagai berikut (Almutairi et al., 2020):

1) Receiving/Attending/Penerimaan
Kategori ini merupakan tingkat afektif yang terendah yang meliputi penerimaan masalah, situasi, gejala, nilai dan keyakinan secara pasif. Penerimaan adalah semacam kepekaan dalam menerima rangsangan atau stimulasi dari luar yang datang pada diri anak.

\section{2) Responding/Menanggapi}

Kategori ini berkenaan dengan jawaban dan kesenangan menanggapi atau merealisasikan sesuatu yang sesuai dengan nilai-nilai yang dianut masyarakat. Atau dapat pula dikatakan bahwa menanggapi adalah suatu sikap yang menunjukkan adanya partisipasi aktif untuk mengikutsertakan dirinya dalam fenomena tertentu dan membuat reaksi terhadapnya dengan salah satu cara. Hal ini dapat dicontohkan dengan menyerahkan laporan tugas tepat pada waktunya.

\section{3) Valuing/ Penilaian}

Kategori ini berkenaan dengan memberikan nilai, penghargaan dan kepercayaan terhadap suatu gejala atau stimulus tertentu. Anak tidak hanya mau menerima nilai yang diajarkan akan tetapi berkemampuan pula untuk menilai fenomena itu baik atau buruk. Hal ini dapat dicontohkan dengan bersikap jujur dalam kegiatan belajar mengajar serta bertanggungjawab terhadap segala hal selama proses pembelajaran.

4) Organization/ Organisasi/ Mengelola

Kategori ini meliputi konseptualisasi nilai-nilai menjadi sistem nilai, serta pemantapan dan prioritas nilai yang telah dimiliki. Hal ini dapat dicontohkan dengan kemampuan menimbang akibat positif dan negatif dari suatu kemajuan sains terhadap kehidupan manusia.

\section{5) Characterization/ Karakterisasi}

Kategori ini berkenaan dengan keterpaduan semua sistem nilai yang telah dimiliki seseorang yang mempengaruhi pola kepribadian dan tingkah lakunya. Proses internalisasi nilai menempati urutan tertinggi dalam hierarki nilai. Hal ini 
dicontohkan dengan bersedianya mengubah pendapat jika ada bukti yang tidak mendukung pendapatnya.

Sebagaimana dijelaskan sebelumnya, bahwa terdapat lima kategori dalam aspek keterampilan (afektif) pada diri anak yang perlu dikembangkan. Salah satunya melalui model pendidikan unschooling, aspek ini tak dibatasi untuk juga dikembangkan. Sebagai contoh, narasumber bersama suami mewadahi anak-anak mereka untuk unjuk diri dengan keterampilan yang mereka sukai, seperti membuat sebuah pagelaran sederhana di rumah. Dimana ada anak yang dapat membacakan puisi, bermain peran (drama), bermain alat musik, dan sebagainya yang dilakukan dihadapan orang rumah. Sebagaimana dikatakan dalam sebuah peribahasa yakni "Take privilage to raise the child", perlu adanya kolaborasi antara orangtua atau orang dewasa di sekitar anak untuk memberikan wahana belajar yang kreatif dan inovatif. Hal tersebut kiranya dapat kita tiru. Selain kesederhanaan sarana pembelajaran, namun dampak dari hal tersebut semakin memberikan kepercayaan dalam diri anak bahwa mereka merasa dihargai orang-orang terdekat dan apa yang mereka sukai juga disukai oleh orang sekitar mereka. Salah satu nilai toleransi yang ditanamkan dalam pengalaman belajar tersebut yakni penghargaan timbal balik sebagai salah satu indikator nilai toleransi. Anak diberikan apresiasi atas unjuk diri yang mereka tampilkan dan anak juga belajar untuk memberikan feedback atas hubungan baik yang diberikan oleh orang sekitar.

G. Aspek Lingkungan dalam Implementasi Model Pendidikan Unschooling sebagai Upaya dalam Mengembangkan Nilai-Nilai Toleransi

Lingkungan merupakan segala sesuatu yang sifatnya eksternal terhadap diri individu, karena lingkungan merupakan sumber informasi yang diperoleh melalui panca indera yang kemudian diterima oleh otak (Djafar,2001 dalam Anwas 2011). Lingkungan menyediakan berbagai fasilitas sebagai bahan pembelajaran. Adapun pernyataan yang mendukung diungkap oleh Sadiman (1986) bahwa lingkungan diasumsikan memiliki keefektifan belajar dalam meningkatkan kemampuan. Di lain sisi, secara umum lingkungan dapat dikelompokkan menjadi tiga, yaitu lingkungan alam atau lingkungan fisik, lingkungan sosial, dan lingkungan budaya. Lingkungan alam atau lingkungan fisik adalah segala sesuatu yang sifatnya alamiah, seperti sumber daya alam (air, hutan, tanah, batu-batuan), tumbuh-tumbuhan dan hewan (flora dan fauna), sungai, iklim, suhu, dan sebagainya. Lingkungan sosial terkait dengan kehidupan bermasyarakat. Lingkungan budaya adalah lingkungan yang sengaja diciptakan atau dibangun manusia untuk tujuan-tujuan tertentu yang bermanfaat bagi kehidupan manusia.

Adapun terkait dengan pemaparan penulis sebelumnya, narasumber juga berbagi pengalaman mengaplikasikan model pendidikan unschooling ini. Ketika penulis menanyakan "Apakah tidak akan membuat anak merasa jenuh bilamana lingkungan belajar adalah lingkungan di sekitar anak tersebut saja?". Narasumber pun menceritakan bahwa bersyukurnya ia dan suami memiliki orangtua yang rumahnya tidak terlalu jauh, sehingga saat hari kerja mereka mengajak anak-anak untuk berkunjung ke rumah kakekneneknya. Dikarenakan kakek dan nenek sudah tidak memiliki anak-anak lagi, sehingga pekerjaan rumah dapat mereka tunda di hari lain dan mereka dapat fokus menemani anak-anak. Ketika anak berada di sekitar orang dewasa, selain lingkungan tersebut aman bagi anak, narasumber juga berpendapat bahwa ketika anak mengalami masalah atau konflik, maka orang dewasa dapat segera merangsang anak untuk mencari solusi dan/atau orang dewasa yang langsung menjadi role model bagi anak.

Bersama kakek-neneknya anak-anak tampak lebih banyak belajar terkait dengan keterampilan sehari-hari, seperti memasak, membersihkan rumah, menyetrika, mencuci, dan sebagainya. Tentunya Lifeskill ini dianggap penting oleh narasumber untuk ditanamkan dalam diri anak, agar kelak anak lebih menghargai dan 
menerapkan nilai-nilai toleransi, seperti tidak sembarangan meletakkan alat makan, lebih berhati-hati saat menjaga pakaian yang dikenakan, dan bertanggung jawab atas kebersihan lingkungan.

Disamping itu, sudah menjadi sebuah rahasia publik yang juga terjadi di lingkup persekolahan di Australia, banyaknya tindakan bullying yang dilakukan antar anak. Hal tersebut tentunya juga tak sedikit terjadi di Indonesia. Banyak faktor penyebab bullying, di antaranya rasa ego anak diusia tersebut yang belum bisa ia kendalikan secara mandiri, sehingga ia ingin merasa lebih dominan dibanding teman-temannya. Hal lain yang juga menjadi faktor penyebab bullying yang dibagikan narasumber pada sesi wawancara adalah keterbatasan guru untuk mengawasi anak-anak yang notabene jumlahnya lebih banyak, dan masih banyak hal lainnya yang menjadi faktor pemantik tindakan bullying tersebut. Tentunya hal tersebut akan berdampak pada diri anak yang menjadi korban bullying. Bukan berarti dengan membatasi anak adalah solusi terbaik untuk menjaga anak kita dari tindakan bullying tersebut. Melainkan perlunya penguatan dalam diri anak, sehingga kelak anak memiliki rasa toleransi yang tinggi terhadap perbedaan dan/ atau hal-hal yang kurang mereka sukai. Salah satu contoh yang diceritakan narasumber terkait fenomena bullying, yakni salah satu teman narasumber memiliki anak yang luar biasa, hingga akhirnya anak tersebut tidak mau pergi sekolah dan lebih memilih untuk berdiam diri di rumah. Berkat kesabaran dan kegigihan kedua orangtuanya melakukan sebuah treatment khusus, sehingga membuat anak menjadi nyaman dan akhirnya dapat menerima keadaan dalam dirinya. Bahkan suatu waktu ketika anak tersebut tertarik dengan bidang arsitek, kedua orangtuanya memfasilitasi, baik melalui penyediaan buku penunjang, guru privat, dan alat-alat media belajar. Suatu ketika anak tersebut ingin membaca buku berkaitan dengan dunia arsitek, padahal pada awalnya anak tersebut belum bisa membaca karena ia berhenti sekolah formal ketika usianya masih terlalu dini, namun karena ketertarikannya pada bidang arsitek, ia gigih untuk bisa membaca dan ia menghabiskan waktu untuk menekuni bidang arsitek tersebut dan ia dapat melanjutkan dan diterima di Universitas Melbourne, yang mana tidak banyak orang yang sulit hingga akhirnya dapat mengenyam pendidikan di salah satu universitas terkemuka di Australia, bahkan salah stau universitas terbaik di dunia. Sungguh, semakin membuka cakrawala hati dan pikiran kita bahwa tidak ada yang dapat membatasi diri untuk berkembang, tentunya diiringi keridhoan Allah SWT.

Dengan demikian, aspek lingkungan sangat berpengaruh dalam pembentukan dan pengembangan nilai-nilai toleransi karena mewadahi individu untuk belajar dan sebagai hal yang tak dapat terlepas dari diri individu tersebut.

\section{Kesimpulan}

Pendidikan karakter merupakan pendidikan budi pekerti yang melibatkan berbagai aspek pengetahuan, sikap, keterampilan, dan lingkungan. Dengan pendidikan karakter yang diterapkan secara sistematis dan berkelanjutan, seorang anak akan memiliki kecerdasan secara emosional. Salah satunya dalam menjiwai dan mengaktualisasikan nilai-nilai toleransi di tengah lapisan masyarakat yang beragam, khususnya terkait hubungan antar umat beragama. Menjadi pribadi yang toleran tidak cukup bagi dirinya sendiri, namun kelak sang anak akan menjadi influencer bagi orang-orang di sekitarnya. Hal ini disebabkan internalisasi nilai-nilai toleransi yang tak lepas dari hubungan timbal balik antar sesama manusia sebagai fitrah ciptaan-Nya. Millions of years of evolution have created children who love to learn on their ownit is how nature has ensured our survival. Humankind has eaten from the tree of knowledge and continues to seek out this delicious fruit from the first moments of life-no force-feeding is necessary. - Kathy Hirsch-Pasek \& Roberta Michnick Golinkoff (Wheatley, 2009).

Sistem pendidikan nasional yang berlaku di Indonesia dimana mewajibkan anak untuk mengenyam pendidikan 
minimal 12 Tahun, tentunya akan lebih maksimal bilamana peran keluarga atau orang terdekat sang anak juga memberikan kontribusi dalam membentuk kepribadian sang anak. Unschooling bukan penolakan terhadap sistem pendidikan, melainkan perjuangan melawan pembatasan pendidikan formal dan optimalisasi pembentukan karakter anak secara utuh. Unschooling bukanlah kesempatan untuk meninggalkan pendidikan yang diperlukan. Ini dianggap sebagai metode yang berbeda untuk mendidik anak yang mengandalkan pendekatan yang lebih hands-off.

\section{Ucapan Terima Kasih}

Ucapan terima kasih penulis kepada narasumber, Brynna Rafferty-Brown selaku Director dan Co-Founder AustraliaIndonesia Cennections (AIC), Praktisi Unschooling di Melbourne, Australia, dan Program Manager Australia-Indonesia Muslim Exchange Program yang telah menjadi subjek dalam validasi dan pengumpulan data aktual berkaitan dengan implementasi model pendidikan unschooling sebagai upaya dalam mengembangkan nilainilai toleransi, dan kepada para kontributor lainnya yang telah membantu penulis, hingga terselesaikannya artikel ini.

Hasil penelitian ini diharapkan dapat memperkaya khasanah ilmu pengetahuan dan memberikan wawasan bagi para pembacanya dalam memahami model pendidikan Unschooling sebagai upaya pengembangan nilai-nilai toleransi dalam diri anak.[]

\section{Daftar Pustaka}

Almutairi, B. A., Alraggad, M. A., \& Khasawneh, M. (2020). The impact of Servant Leadership on Organizational Trust: The Mediating Role of Organizational Culture. European Scientific Journal ESJ, 16(16), 1-10. h t t p s://d oi.org/10.19044/ esj.2020.v16n16p49

Anwas, O. M. (2011). Lingkungan sebagai Media Pembelajaran dan Pengaruhnya terhadap Kompetensi Penyuluh
Pertanian. Jurnal Pendidikan Dan Kebudayaan, 17(3), 283. https://doi.org/ 10.24832/jpnk.v17i3.24

Azoulay, A. (2017). International Day for Tolerance-16 November 2017. UNESCO. http://www.unesco.org/new/en/ unesco/events/prizes-andcelebrations/celebrations/ international-day-for-tolerance/

Beard, J. R., \& Beard, C. (1968). Cassel's Latin Dictionary: Latin-English, English-Latin.

Ceadel, M. (1983). HANDBOOK OF PEACE AND CONFLICT STUDIES. Dalam Studies in Church History (Vol. 20). h t t p s://doi.org/10.1017/ s0424208400007403

Deci, E. L., \& Ryan, R. M. (2008). Facilitating optimal motivation and psychological well-being across life's domains. Canadian Psychology, 49(1), 14-23. https://doi.org/10.1037/07085591.49.1.14

Eleesha Lockett, M. (2019). What Is Unschooling and Why Do Parents Consider It? Healthline. https:// www.healthline.com/health/childrenshealth/unschooling

Gray, P. \& G. R. (2013). The Challenges and Benefits of Unschooling, According to 232 Families Who Have Chosen that Route. Journal of Unschooling $\mathcal{E}$ Alternative Learning, 7(14), 1-27. https:/ /acces.bibl.ulaval.ca/login? url=https:/ /search.ebscohost.com/login.aspx? direct $=$ true \&db= eue\&AN= 91024647 \&lang $=$ fr\&site $=$ ehost-live

Hadisaputra, P. (2020). Implementasi Pendidikan Toleransi di Indonesia. Dialog, 43(1), 75-88. https://doi.org/ 10.47655/dialog.v43i1.355

Holt, J. (1967). How children fail. Pitman Publishing Company.

Indonesia, P. R. (2003). UNDANG-UNDANG REPUBLIK INDONESIA NOMOR 20 TAHUN 2003 TENTANG SISTEM PENDIDIKAN NASIONAL (Patent No. 20). file:///E:/C\&R/JURNAL 
HARMONI/Sumber Data/UU Nomor 20 Tahun 2003.pdf

Keifer, G., \& Effenberger, F. (1967). Unschooling: Education Outside the Box. Angewandte Chemie International Edition, 6(11), 951-952.

Marhayati, N., Chandra, P., \& Fransisca, M. (2020). Pendekatan Kognitif Sosial pada Pembelajaran Pendidikan Agama Islam. DAYAH: Journal of Islamic Education, 3(2), 250. https://doi.org/ 10.22373/jie.v3i2.7121

Nurihsan, Y. S. dan A. J. (2009). Landasan dan Bimbingan Konseling. PT Remaja Rosdakarya.

Nurwati, A. (2014). Penilaian Ranah Psikomotorik Siswa Dalam Pelajaran Bahasa. Edukasial : Jurnal Penelitian Pendidikan Islam, 9(2), 385-400. https:// doi.org/10.21043/edukasia.v9i2.781

Nuswantari, N. (2018). Model pembelajaran nilai-nilai toleransi untuk anak sekolah dasar. Premiere Educandum/ : Jurnal Pendidikan Dasar Dan Pembelajaran, 8(1), 41. https://doi.org/10.25273/ pe.v8i1.2255

Rahmah, A., Nur, L., Kastrena, E., Istiqomah, A., \& City, T. (2019). Peningkatan Kemampuan Gerak Manipulatif. 9, 48-65.

Riley, G. (2018). UNSCHOOLING/ : A DIRECT EDUCATIONAL APPLICATION OF DECI AND RYAN' S ( 1985 ) SELF DETERMINATION THEORY AND COGNITIVE EVALUATION UNSCHOOLING/: A DIRECT EDUCATIONAL APPLICATION OF DECI AND RYAN' S ( 1985 ) SELF DETERMINATION THEORY AND. March. https://doi.org/ 10.5281/zenodo.1193960

Si Kecil Peniru Alami. (2021). https:// www.ibudanbalita.com/artikel/sikecil-peniru-alami?page $=2$

Syah, M. (2012). Psikologi Belajar. Rajawali Pers.

Tillman, D. (2001). Living Values Activities for Children Ages 8-14.
Tillman, D. (2004). Living values activities for children ages 8-14 (terjemahan Adi respati dkk) (Educationa).

Wheatley, K. F. (2009). Unschooling: An Oasis for Development and Democracy. Education for Meaning and Social Justice, 2.

Yuslaini. (2018). PENDIDIKAN KARAKTER DI INDONESIA/ : UNIVERSITAS ISLAM NEGERI RADEN INTAN LAMPUNG.

Zulfi, N., Islam, U., Sunan, N., Surabaya, A., Tarbiyah, F., Keguruan, D. A. N., Pendidikan, J., Dan, M., Studi, P., \& Matematika, P. (2018). Profil penyebab beban kognitif siswa dalam pembelajaran matematika ditinjau dari kemampuan awal siswa. 